\title{
Pengaruh model pembelajaran kooperatif tipe think talk write (TTW) terhadap kemampuan pemecahan masalah matematika siswa kelas XI MIA SMA NW Mataram Tahun Pelajaran 2019/2020
}

\author{
Aena Malini ${ }^{1 *}$, Nurul Hikmah², Wahidaturrahmi ${ }^{3}$, Laila Hayati ${ }^{4}$ \\ ${ }^{1}$ Mahasiswa Pendidikan Matematika, FKIP, Universitas Mataram, Mataram \\ 2 Pendidikan Matematika, FKIP, Universitas Mataram, Mataram
}

Aenamalini@gmail.com

Received: 15-12-2021 ; Revised: 31-12-2021; Published: 31-12-2021

\begin{abstract}
This research aims to determine the effect of Think Talk Write (TTW) cooperative learning model towards the ability of mathematics problem solving of grade XI MIA SMA NW Mataram academic year 2019/2020. Type of the research is a quasi-experimental design with a posttest only control design. The population of the research is all students grade XI MIA SMA NW Mataram academic year 2019/2020. The sampling technique was saturated sampling tecnique, so the sample obtained that XI MIA 1 as the experimental class and XI MIA 2 as the controlling class. The instrument used was a test of the students learning achievement (posttest) on the sequence and series material. Quantitave analysis obtained by using $t$-test. The result of this research showed that there is a difference in the average score of students who get learning use the Think Talk Write (TTW) cooperative learning models with students who use direct learning. Meanwhile the effect of Think Talk Write (TTW) cooperative learning model towards the ability of mathematics problem solving of using the effect size with moderate category. This means that the Think Talk Write (TTW) type of cooperative learning models is quite influential on the mathematics problem solving ability of grade XI MIA SMA NW Mataram.
\end{abstract}

Keywords: cooperative learning method; think talk write; mathematics problem solving

\begin{abstract}
Abstrak
Penelitian ini bertujuan untuk mengetahui pengaruh model pembelajaran kooperatif tipe Think Talk Write (TTW) terhadap kemampuan pemecahan masalah matematika siswa kelas XI MIA SMA NW Mataram tahun pelajaran 2019/2020. Jenis penelitian adalah quasi eksperimen dengan desain posttest only control design. Populasi dalam penelitian ini adalah seluruh siswa kelas XI SMA NW Mataram tahun pelajaran 2019/2020. Teknik pengambilan sampel yakni dengan teknik sampling jenuh karena semua anggota populasi digunakan sebagai sampel, sehingga diperoleh sampel kelas XI MIA 1 sebagai kelas ekperimen dan kelas XI MIA 2 sebagai kelas kontrol. Instrumen yang digunakan adalah tes hasil belajar siswa (post-test) pada materi barisan dan deret. Analisis kuantitatif dilakukan dengan menggunakan uji-t. Hasil penelitian menunjukkan bahwa terdapat perbedaan nilai rata-rata siswa yang memperoleh pemebelajaran menggunakan model pembelajaran kooperatif tipe Think Talk Write (TTW) dengan siswa yang menggunakan pembelajaran langsung. Sedangkan besar pengaruh model pembelajaran kooperatif tipe Think Talk Write (TTW) terhadap kemampuan pemecahan masalah matematika diukur menggunakan effect size dengan kategori sedang. Hal ini berarti model pembelajaran kooperatif tipe Think Talk Write (TTW) cukup berpengaruh terhadap kemampuan pemecahan masalah matematika siswa kelas XI MIA SMA NW Mataram.
\end{abstract}

Kata Kunci: model pembelajaran kooperatif; think talk write; pemecahan masalah matematika 


\section{PENDAHULUAN}

Pendidikan merupakan aspek penting yang akan menentukan kualitas kehidupan seseorang dan suatu bangsa, dimana pendidikan tersebut diberikan secara formal ataupun informal. Matematika merupakan salah satu bidang studi yang sangat penting dalam dunia pendidikan, karena matematika selalu dijumpai dalam setiap jenjang pendidikan. Matematika sering dianggap sebagai salah satu mata pelajaran yang sulit dipahami. Hal ini disebabkan oleh kurangnya siswa memahami mata pelajaran matematika termasuk dalam menyelesaikan masalah-masalah matematika.

Matematika memiliki peran yang penting dalam pendidikan karena matematika adalah ilmu dasar pengetahuan yang digunakan secara luas dalam berbagai bidang kehidupan. Menurut Permendiknas Nomor 22 (2006: 346) salah satu tujuan pembelajaran matematika pada pendidikan menengah adalah agar siswa memiliki kemampuan memecahkan masalah yang meliputi kemampuan memahami masalah, merancang model matematika, menyelesaikan model dan menafsirkan solusi yang diperoleh. Kemampuan pemecahan masalah merupakan suatu aspek penting yang harus dimiliki siswa.

Kemampuan pemecahan masalah untuk siswa sangat penting karena kemampuan pemecahan masalah merupakan kemampuan matematis yang esensial untuk siswa. Pentingnya memiliki kemampuan pemecahan masalah matematis sejak lama telah dikemukakan Branca (dalam Purwosusilo, 2014) yaitu sebagai berikut: (1) kemampuan pemecahan masalah merupakan tujuan umum pengajaran matematik, bahkan sebagai jantungnya matematika. (2) penyelesaian masalah meliputi metode, prosedur, strategi dalam pemecahan masalah merupakan proses inti dan utama dalam kurikulum matematika. (3) pemecahan masalah merupakan kemampuan dasar dalam belajar matematika. Menurut Hikmawati, et.al (2019) kemampuan pemecahan masalah adalah kemampuan seseorang untuk menemukan solusi melalui suatu proses yang melibatkan pemerolehan dan pengorganisasian informasi. Sedangkan menurut Sudjana (2010:116) kemampuan pemecahan masalah adalah upaya yang dilakukan siswa untuk mencari dan menetapkan alternatif kegiatan dalam menjembatani suatu keadaan pada saat ini dengan keadaan yang diinginkan. Hal ini berarti bahwa kemampuan pemecahan masalah merupakan hal yang harus mendapat perhatian, mengingat peranannya yang sangat strategis dalam mengembangkan kemampuan berpikir siswa.

Namun pada kenyataannya, berdasarkan hasil wawancara dengan salah satu guru mata pelajaran matematika di SMA NW Mataram selama melaksanakan program praktek lapangan (PPL) di SMA NW Mataram, Guru mata pelajaran matematika di SMA NW Mataram mengatakan bahwa salah satu faktor yang menjadi penyebab rendahnya pemecahan masalah matematika siswa karena: 1) Siswa masih kesulitan dalam memahami konsep materi yang disampaikan, sebab siswa kurang memperhatikan penjelasan guru saat menyampaikan materi. 2) Saat diberikan kesempatan untuk bertanya tidak ada siswa yang mengacungkan tangan untuk bertanya kepada guru 
tentang materi yang belum dipahami. 3) Ketika diberikan soal latihan berupa soal cerita, masih banyak siswa yang hanya mampu menuliskan apa yang diketahui dan yang ditanyakan, sedangkan untuk tahap selanjutnya siswa tidak bisa melanjutkannya. 4) Siswa kurang fokus dalam pembelajaran dikelas sebab sibuk dengan kegiatan masingmasing, seperti bercerita dengan teman sebangku saat guru sedang menjelaskan materi.

Namun demikian siswa kelas XI MIA di SMA NW Mataram memiliki potensi diantaranya siswa terlihat antusias pada saat belajar kelompok, ada kemauan untuk bertanya kepada temannya dibandingkan kepada guru dan ada kemauan untuk menyampaikan pendapat pada teman pada saat pembelajaran berkelompok. Oleh sebab itu, diperlukan model pembelajaran yang efektif sehingga membuat siswa lebih aktif dalam proses pembelajaran, lebih mudah menemukan dan memahami konsep-konsep yang sulit jika mereka saling mendiskusikan masalah yang ada dengan temannya. Salah satu model pembelajaran yang dapat digunakan dalam mengatasi kesulitan siswa dan mengoptimalkan potensi-potensi yang ada pada siswa dalam mempelajari matematika adalah model pembelajaran kooperatif tipe Think Talk Write (TTW). Model pembelajaran kooperatif tipe TTW pada dasarnya dibangun melalui berpikir, berbicara, dan menulis. Model pembelajaran kooperatif tipe TTW ini mempunyai kelebihan yaitu keterlibatan siswa dalam berpikir atau berdialog dengan dirinya sendiri setelah proses membaca, selanjutnya berpikir dan membagi ide dengan temannya sebelum menulis (Isrok'atun dan Rosmala, 2018: 154) Alur dari model pembelajaran kooperatif tipe TTW yang dimulai dari berpikir, berbicara, dan menulis diharapkan dapat meningkatkan kemampuan pemecahan masalah matematika pada siswa.

\section{METODE PENELITIAN}

Jenis penelitian yang digunakan adalah penelitian eksperimen semu (Quasi Eksperiment) yang bertujuan untuk mengetahi ada tidaknya pengaruh dari suatu perlakuan yang dikenakan pada subyek penelitian yang dilakukan oleh peneliti (Sugiyono, 2013:114), dengan desain Posttest Only Control Design. Desain ini digunakan karena hanya terdapat dua kelas yaitu kelas ekperimen dan kelas kontrol dimana satu diantaranya diterapkan pembelajaran dengan model pembelajaran kooperatif tipe Think Talk Write (TTW) yaitu kelas eksperimen dan yang lain diterapkan pembelajaran langsung yaitu kelas control. Penelitian ini akan dilaksanakan SMA NW Mataram pada semester ganjil tahun pelajaran 2019/2020.

Populasi penelitian adalah seluruh siswa kelas XI MIA di SMA NW Mataram yang terdistribusi dalam 2 kelas, yaitu seluruh siswa kelas XI MIA di SMA NW Mataram tahun pelajaran 2019/2020 sebanyak 32 siswa, teknik pemgambilan sampel yang digunakan dalam penelitian ini adalah teknik sampling jenuh. Dalam peneliti ini hanya terdapat dua kelas sebagai kelas eksperimen dan kelas kontrol yang akan di jadikan penelitian dan pengambilan data. Dimana kelas XI MIA 1 sebagai kelas ekspermen yang akan dikenai model pembelajara Think Talk Write (TTW) dan kelas XI MIA 2 sebagai kelas kontrol yang akan dikenai model pembelajaran konvensional. 
Teknik pengumpulan data yang digunakan dalam penelitian ini adalah teknik tes. Tes dalam hal ini adalah intrumen pengumpulan data berupa seperangkat pertanyaan/soal untuk memperoleh data mengenai kemampuan pemecahan masalah pada siswa. Dalam penelitian ini tes berfungsi untuk menguji hasil belajar matematika setelah model pembelajaran Think Talk Write (TTW) diterapkan.

Analisis data dilakukan dengan tahapan uji normalitas, uji homogenitas, dan uji hipotesisi yaitu uji-t yang merupakan statistik yang diguanakan untuk mengetahui apakah rata-rata hitung antara dua kelompok sampel yang dibandingkan mempunyai perbedaan yang signifikan (meyakinkan) atau tidak (Purwanto, 2017:156). Dimana uji- $t$ menggunakan polled varians dan uji effect Size. Polled varians dilakukan untuk mengetahui ada atau tidaknya perbedaan yang signifikan (meyakinkan) dari dua buah sampel yang dibandingkan. Sedangkan uji fect Size digunakan untuk mengetahui besar pengaruh model pembelajaran kooperatif tipe Think Talk Write (TTW) terhadap pemecahan masalah matematika siswa kelas XI MIA SMA NW Mataram.

\section{HASIL DAN PEMBAHASAN}

Sebelum pengujian Uji-t dilakukan, terlebih dulu dilakukan uji normalitas dan uji homogenitas. Uji normalitas data dilakukan untuk meguji data sampel berasal dari populasi yang berdistribusi normal atau tidak. Pada penelitian ini pengujian menggunakan uji Liliefors dimana kriteria untuk menguji normalitas yaitu nilai Lhitung<Ltabel pada taraf signifikansi 5\%, maka data post-test matematika siswa berdistribusi normal. Setelah dilakukan perhitungan uji normalitas diperoleh data seperti yang disajikan pada Tabel 1.

Tabel 1. Hasil Uji Normalitas Data Post-test

\begin{tabular}{lllll}
\hline Kelas & $L_{\text {hitung }}$ & $L_{\text {tabel }}$ & $\begin{array}{l}\text { Keputusan } \\
\text { Uji }\end{array}$ & Kesimpulan \\
\hline $\begin{array}{l}\text { XI MIA 2 } \\
\text { (kelas eksperimen) }\end{array}$ & 0,099 & 0,206 & & $H_{\text {hitung }}<L_{\text {tabel }}$ \\
\cline { 1 - 2 } $\begin{array}{l}\text { XI MIA 1 } \\
\text { (kelas kontrol) }\end{array}$ & 0,179 & 0,22 & & $H_{0}$ diterima \\
\hline
\end{tabular}

Berdasarkan Tabel 1 terlihat hasil uji normalitas post-test menggunakan uji Liliefors diperoleh nilai $L_{\text {hitung }}<L_{\text {tabel }}$. Sehingga $H_{0}$ diterima, maka data dari nilai post-test kelas eksperimen dan kelas control berasal dari populasi yang berdistribusi normal.

Uji homogenitas dilakukan untuk memperoleh asumsi bahwa data post-test dari sampel penelitian ini memiliki variansi yang sama atau homogen. Dalam penelitian ini untuk menguji homogenitas, peneliti menggunakan Uji Bartlett. Setelah dilakukan perhitungan uji homogenitas diperoleh data seperti yang disajikan pada Tabel 2. 
Tabel 2. Hasil Uji Homogenitas Data Post-test

\begin{tabular}{|c|c|c|c|c|}
\hline Uji Homogenitas & $\chi_{\text {hitung }}^{2}$ & $\chi_{\text {tabel }}^{2}$ & Keputusan uji & $\begin{array}{l}\text { Kesimpula } \\
\mathrm{n}\end{array}$ \\
\hline $\begin{array}{l}\text { Nilai Post-test Matematika } \\
\text { Kelas XI MIA } 1 \text { Dan XI MIA } \\
2\end{array}$ & 1,621 & 3,841 & $\chi_{\text {hitung }}^{2}<\chi_{\text {tabel }}^{2}$ & $\begin{array}{r}H_{0} \\
\text { diterima }\end{array}$ \\
\hline
\end{tabular}

Berdasarkan Tabel 2 terlihat hasil uji homogenitas post-test menggunakan Uji Bartleh diperoleh nilai $x_{\text {hitung }}^{2}<x_{\text {tabel }}^{2}$ maka $H_{0}$ diterima. Sehingga data dari nilai post-test kelas eksperimen dan kelas kontrol memiliki variansi yang sama (homogen).

Tabel 3. Hasil Uji- $t$ Data Post-test

\begin{tabular}{llcccc}
\hline Kelas & $\begin{array}{l}\text { Jumlah } \\
\text { siswa }\end{array}$ & $\overline{\bar{X}}$ & $s^{2}$ & $t_{\text {hitung }}$ & $t_{\text {tabel }}$ \\
\cline { 1 - 4 } XI MIA 1 & 15 & 78,118 & 114,429 & & \\
\cline { 1 - 3 } XI MIA 2 & 17 & 71,000 & 59,110 & 2,180 & 2,042 \\
\hline
\end{tabular}

Berdasarkan Tabel 3, diperoleh nilai $t_{\text {hitung }}>t_{\text {tabel }}$ pada taraf signifikansi $5 \%$, maka $H_{0}$ ditolak. Sehingga, dapat disimpulkan rata-rata kemampuan pemecahan masalah matematika kelas eksperimen yang menggunakan model pembelajaran kooperatif tipe Think Talk Write (TTW) lebih besar dari rata-rata kemampuan pemecahan masalah matematika kelas kontrol yang menggunakan model pembelajaran langsung. Oleh karena itu, dapat dikatakan terdapat pengaruh kemampuan pemecahan masalah matematika siswa yang signifikan antara kelas yang diterapkan model pembelajaran kooperatif tipe Think Talk Write (TTW) dan kelas yang diterapkan model pembelajaran langsung pada siswa kelas XI MIA SMA NW Mataram.

Untuk mengetahui seberapa besar pengaruh model pembelajaran kooperatif tipe Think Talk Write (TTW) terhadap pemecahan masalah matematika siswa kelas XI MIA SMA NW Mataram, dapat dilakukan dengan perhitungan effect size dengan rumus Cohen's diperoleh pada Tabel 4.

Tabel 4. Data Hasil uji Effect Size

\begin{tabular}{lrrrrrl}
\hline & $n_{1}$ & $n_{2}$ & $\bar{X}_{1}$ & $\bar{X}_{2}$ & $S_{\text {polled }}$ & $D$ \\
\hline 17 & 15 & 78,118 & 71,000 & 2,180 & 0,7 \\
\hline
\end{tabular}

Berdasarkan Tabel 4 diketahui bahwa hasil uji effest size (d) adalah 0,7 kemudian disesuaikan dengan tabel kriteria interpretasi uji effect size bahwa nilai $0,2<d \leq 0,8$ Maka dapat disimpulkan bahwa model pembelajaran kooperatif tipe Think Talk Write 
(TTW) berpengaruh terhadap pemecahan masalah matematika siswa kelas XI MIA SMA NW Mataram yaitu dengan kategori sedang yaitu $76 \%$.

Penelitian ini merupakan penelitian eksperimen yang bertujuan untuk melihat pengaruh model pembelajaran kooperatif tipe Think Talk Write (TTW) terhadap kemampuan pemecahan masalah matematika siswa kelas XI MIA SMA NW mataram. Pada penelitian ini kelas XI MIA 1 sebagai kelas eksperimen diterapkan model pembelajaran kooperatif tipe Think Talk Write (TTW) dan kelas XI MIA 2 sebagai kelas kontrol diterapkan model pembelajaran langsung.

Pada kelas eksperimen peneliti menggunakan model pembelajaran kooperatif Think Talk Write (TTW) dalam proses pembelajaran. Dengan menggunakan model pembelajaran TTW lebih tertarik dalam proses pembelajaran. Hal ini dikarenakan dengan model pembelajaran TTW ini para siswa diajak untuk memikirkan jawaban dari permasalahan yang diajukan, siswa melakukan diskusi kelompok untuk mengerjakan lembar kerja siswa (LKS) dimana LKS ini diracang dan disusun untuk menemukan rumus, konsep atau prinsip matematika yang menjadi tujuan pembelajaran serta dapat meningkatkan kemampuan pemecahan masalah matematika siswa.

Dengan penerapan model pembelajaran kooperatif tipe TTW tersebut maka kemampuan pemecahan masalah siswa menjadi lebih baik. Hal ini sejalan dengan hasil penelitian yang dilakukan oleh Jano (2015) yang menyatakan bahwa, model pembelajaran TTW menggunakan langkah-langkah penyelesaian yang urut dan mudah dipahami siswa serta selama proses pembelajaran dengan model ini, usaha para siswa untuk belajar terwujud dengan baik.

Melalui model pembelajaran TTW ini kemampuan pemecahan masalah siswa menjadi lebih baik. Hal ini menunjukkan bahwa model ini bisa digunakan pendidik saat melakukan pembelajaran matematika di masa yang akan datang. Hal ini diperkuat dengan hasil penelitian Sopiany dan Hijjah (2016) yang menyatakan bahwa, penggunaan model pembelajaran TTW dapat digunakan guru untuk meningkatkan kemampuan pemecahan masalah siswa. Sejalan dengan hasil penelitian Fajar, dkk (2016) yang menyatakan bahwa, guru dapat menerapkan model pembelajaran TTW secara berkelanjutan pada pembelajaran matematika sehingga kemampuan pemecahan masalah siswa pada dapat dikembangkan.

Disamping itu pada think (berpikir) ini siswa secara individu memikirkan kemungkinan jawaban atau strategi penyelesaian, membuat catatan kecil tentang ide-ide yang terdapat pada bacaan, dan hal-hal yang tidak dipahaminya sesuai dengan bahasanya sendiri. Menurut Suyanto (2009) proses ini dimulai dengan berfikir melalui bahan bacaan, hasil bacaan dikomunikasikan dengan presentasi diskusi kemudian membuat laporan hasil diskusi. Aktivitas berpikir dapat dilihat dari proses membaca suatu teks matematika atau berisi cerita matematika kemudian membuat catatan tentang apa yang telah dibaca (dalam Chandra, Fauzan, dan Helma, (2011). Dalam membuat atau menulis 
catatan siswa membedakan dan mempersatukan ide yang disajikan dalam teks bacaan, kemudian menerjemahkan kedalam bahasa mereka sendiri.

Tahap terakhir adalah write (menulis). Masingila dan Wisniowska (1996:95) (dalam Sukarini, 2020) mengatakan bahwa manfaat tulisan siswa untuk guru adalah (1) komunikasi langsung secara tertulis dari seluruh anggota kelas, (2) informasi tentang kesalahan-kesalahan, miskonsepsi, kebiasaan berpikir, dan keyakinan dari para siswa, (3) variansi konsep siswa dari ide yang sama, dan (4) bukti yang nyata dari pencapaian atau prestasi siswa. Aktivitas menulis siswa pada tahap ini meliputi: menulis solusi terhadap masalah/pertanyaan yang diberikan termasuk perhitungan, mengorganisasikan semua pekerjaan langkah demi langkah, mengoreksi semua pekerjaan sehingga yakin tidak ada perkerjaan ataupun perhitungan yang ketinggalan, dan meyakini bahwa pekerjaannya yang terbaik, yaitu lengkap, mudah dibaca dan terjamin keasliannya. Pada tahap ini siswa akan belajar untuk melakukan koneksi matematika secara tertulis. Berdasarkan hasil diskusi, siswa dimita untuk menuliskan penyelesaian dan kesimpulan dari masalah yang telah diberikan.

Sebelum peneliti memberikan post-test kepada kelas eksperimen dan kelas kontrol, terlebih dahulu peneliti melakukan validitas agar item soal post-test yang digunakan untuk mengetahui hasil belajar siswa valid atau tidak. Peneliti membuat 4 soal yang sesuai dengan materi yang dis ampaikan. Soal yang telah dibuat peneliti ini terlebih dahulu didiskusikan dengan dosen pembimbing dan divalidasi oleh dosen penguji/validator dan guru matematika kelas XI. Hal ini dilakukan untuk memberikan kritik dan saran bagi peneliti dari ahli terhadap sebuah instrumen sehingga instrumen tersebut dapat digunkaan dengan baik untuk mengukur variabel yang ingin diukur.

Pada saat melaksanakan penelitian, peneliti melakukan 4 kali pertemuan terhadap kelas eksperimen maupun kelas kontrol. Dimana 3 kali pertemuan tersebut untuk melakukan proses pembelajaran dan satu kali digunakan untuk melakukan post-test. Pada saat melaksanakan penelitian secara umum telah sesuai dengan langkah-langkah pembelajaran yang ada sesuai dengan langkah-langkah pembelajaran yang terdapat pada rencana pelaksanan pembelajaran yang telah disusun.

Setelah melakukan proses pembelajaran sebanyak empat kali pertemuan kemudian peneliti melakukan test akhir (post-test) untuk melihat pemahaman siswa terhadap materi barisan dan deret nilai post-test yang telah terkumpul kemudian dianalisis menggunakan uji- $t$ sebelum melakukan pengujian hipotesis dengan menggunakan uji- $t$ terlebih dulu melakukan uji normalitas dan uji homogenitas. Setelah data nilai post-test berdistribusi normal dan homogen kemudian dilanjutkan pengujian hipotesis dengan rumus polled varians dikarenakan jumlah siswa kelas eksperimen tidak sama dengan jumlah siswa kelas kontrol tetapi data dari nilai post-test kelas eksperimen dan kelas kontrol memiliki variansi yang sama (homogen). 
Hasil penelitian ini sejalan dengan penelitian yang dilakukan oleh Afriyani, Chotim, dan Hidayah (2014) menunjukkan bahwa model pembelajaran TTW sangat efektif terhadap kemampuan pemecahan masalah matematik siswa. Riansyah dan Sari (2018) menyimpulkan ada pengaruh model pembelajaran kooperatif tipe TTW berpengaruh terhadap kemampuan pemecahan masalah matematika siswa, yaitu dilihat dari hasil rata-rata kemampuan pemecahan masalah matematika siswa kelas eksperimen lebih besar dari kelas control.

Untuk mengetahui besarnya pengaruh model pembelajaran kooperatif tipe TTW terhadap kemampuan pemecahan masalah matematika dihitung menggunakan effect size dengan rumus Cohen's. Sejalan dengan penelitian Diani, Asyhari, dan Julia (2018) effect size juga dapat diangap sebagai ukuran mengenai tingkat keberhasilan peneliti. Dari perhitungan effect size dengan rumus Cohen's diperoleh hasil dengan kategori sedang. Sehingga dapat dikatakan bahwa model pembelajaran kooperatif tipe Think Talk Write (TTW) cukup berpengaruh terhadap pemecahan masalah matematika siswa.

Dengan demikian, berdasarkan pembahasan diatas dapat disimpulkan bahwa pembelajaran dengan model pembelajaran kooperatif tipe Think Talk Write (TTW) berpengaruh terhadap kemampuan pemecahan masalah matematika siswa kelas XI SMA NW Mataram tahun pelajaran 2019/2020.

\section{SIMPULAN}

Berdasarkan hasil analisis data yang telah dibahas sebelumnya dapat disimpulkan bahwa terdapat pengaruh model pembelajaran kooperatif tipe Think Talk Write (TTW) terhadap kemampuan pemecahan masalah matematika pada siswa kelas XI MIA SMA NW Mataram tahun pelajaran 2019/2020. Hal ini dapat dilihat dari pengujian hipotesis dengan uji-t yaitu, nilai rata-rata kemampuan pemecahan masalah matematika kelas eksperimen yang menggunakan model pembelajaran kooperatif tipe Think Talk Write (TTW) lebih besar dari nilai rata-rata kemampuan pemecahan masalah matematika kelas kontrol yang menggunakanpem pembelajaran langsung.

Penelitian ini diharapkan dapat membantu siswa berperan aktif dalam pembelajaran matematika di kelas, mudah dalam memahami materi yang diajarkan serta meningkatkan kemampuan pemecahan masalah siswa. Guru juga diharapkan dapat menerapkan model pembelajaran Think Talk Write (TTW) sebagai alternatif dalam pembelajaran sehingga proses pembelajaran tidak monoton dan dapat meningkatkan hasil kemampuan pemecahan masalah matematika siswa.

\section{REFERENSI}

Afriyani, A. D. N., Chotim, M., dan Hidayah, I. 2014. Keefektifan Pembelajaran TTW Dan SGW berbantuan Kartu Soal Terhadap Kemampuan Pemecahan Masalah. Unnes Journal of Mathematics Education. 3(1), 48-55. 
Chandra, S. R., Fauzan, A., dan Helma. 2014. Pengaruh Model Pembelajaran Tipe Think Talk Write Dan Gender Terhadap Kemampuan Komunikasi Matematis Siswa Kelas VIII SMPN 12 Padang. Jurnal Pendidikan Matematika. 3(1), 35-40.

Diani, R., Asyhari., A. dan Julia, O. N. (2018). Pengaruh Model RMS (Reading, Mind Mapping And Sharing) Terhadap Kemampuan Berpikir Tingkat Tinggi Siswa Pada Pokok Bahasan Impuls Dan Momentum. Jurnal Pendidikan Edutama. 5(1), 31-43.

Fajar, L. O. M. S., \& Sudia. M. (2016). Penerapan Model Pembelajaran TTW (Think Talk Write) Sebagai Upaya Meningkatkan Kemampuan Pemecahan Masalah Matematika Siswa Kelas VIII-5 SMP N 2 Raha. Jurnal Penelitian Pendidikan Matematika. 4(1), 85-96.

Hikmawati., Fatimah, Z., \& Wahyudi. (2019). Pengaruh Model Pembelajaran Generatif Dengan Teknin Guided Teaching Terhadap Kemampuan Pemecahan Masalah Fisika Kelas XI. Konstan- Jurnal Fisika dan Pendidikan Fisika. 4(1), 20-31

Isrok'atun, dan Rosmala, A. 2018. Model-Model Pembelajaran Matematika. Jakarta: Sinar Grafika Offset.

Jano, A. 2015. Pengaruh Model TTW Berbantuan Media Gambar Terhadap Hasil Belajar Bahasa Indonesia Siswa SD Kelas IV. Jurnal pendidikan. 3(1), 1-10.

Peraturan Menteri Pendidikan Nasional RI Nomor 22 Tahun 2006 Tentang Standar Isi. 2006. Jakarta Menteri Pendidikan Nasional.

Purwanto. 2017. Evaluasi Hasil Belajar. Yogyakarta: Pustaka Pelajar.

Purwosusilo. 2014. Peningkatan Kemampuan Pemahaman Dan Pemecahan Masalah Matematik Siswa SMK Melalui Strategi Pembelajaran React. Jurnal Pendidikan dan Keguruan Vol. 1 No 2. 30-40

Riyansyah, F. dan Sari, A. 2018. Pengaruh Penerapan Pembelajaran Kooperatif Tipe Think Talk Write (TTW) Terhadap Kemampuan Pemecahan Masalah Matematika Ditinjau Dari Kemampuan Awal Matematika. Journal for Research in Mathematics Learning. 1(2), 119126.

Sopiany, N.H., \& Hijjah, I. S. (2016). Penggunaan Strategi TTW (Think-Talk-Write) Dengan Pendekatan Kontekstual Dalam Meningkatkan Kemampuan Pemecahan Masalah Dan Disposisi Matematis Siswa MTsN Rawamerta Karawang. Jurnal JPPM. 9(2). 268-276.

Sudjana, N. (2010). Cara Belajar Siswa Aktif dalam Proses Belajar Mengajar. Bandung. Sinar Baru Algensind.

Sugiyono. 2013. Metode Penelitian Kombinasi. Bandung: Alfabeta.

Sukarini, N.K. 2020. Penerapan Model Pembelajaran Kooperatif Tipe Think Talk Write Untuk Meningkatkan Hasil Belajar Matematika Siswa. Jurnal Pendidikan Matematika Undiksha. $11(1), 12-21$. 